\title{
Discrepancy in Programmed Cell Death-Ligand 1 Between Primary and Metastatic Non-small Cell Lung Cancer
}

\author{
SHINKICHI TAKAMORI ${ }^{1}$, GOUJI TOYOKAWA $^{1}$, ISAMU OKAMOTO $^{2}$, KAZUKI TAKADA $^{1,3}$, \\ YUKA KOZUMA $^{1}$, TAICHI MATSUBARA ${ }^{1}$, NAOKI HARATAKE ${ }^{1}$, TAKAKI AKAMINE ${ }^{1}$, \\ MASAKAZU KATSURA ${ }^{1}$, NOBUTAKA MUKAE ${ }^{4}$, FUMIHIRO SHOJI ${ }^{1}$, TATSURO OKAMOTO ${ }^{1}$, \\ YOSHINAO ODA $^{3}$, TORU IWAKI ${ }^{5}$, KOJI IIHARA ${ }^{4}$, YOICHI NAKANISHI ${ }^{2}$ and YOSHIHIKO MAEHARA ${ }^{1}$ \\ ${ }^{1}$ Department of Surgery and Science, Graduate School of Medical Sciences, Kyushu University, Fukuoka, Japan; \\ ${ }^{2}$ Research Institute for Disease of the Chest Graduate School of Medical Sciences, \\ Kyushu University, Fukuoka, Japan; \\ ${ }^{3}$ Department of Anatomic Pathology, Graduate School of Medical Sciences, Kyushu University, Fukuoka, Japan; \\ ${ }^{4}$ Department of Neurosurgery, Graduate School of Medical Sciences, Kyushu University, Fukuoka, Japan; \\ ${ }^{5}$ Department of Neuropathology, Neurological Institute, \\ Graduate School of Medical Sciences, Kyushu University, Fukuoka, Japan
}

\begin{abstract}
Aim: To investigate the discordance in the programmed cell death-ligand 1 ( $P D-L 1)$ expression between primary and metastatic tumors and analyze the association between the discordance and the clinical factors in non-small cell lung cancer (NSCLC) patients. Patients and Methods: Twenty-one NSCLC patients who underwent surgery or biopsy for paired primary and metastatic lesions at our Institution from 2005 to 2016 were analyzed. Lesions with the PD-L1 expression being $\geq 5 \%$ were considered PD-L1-positive. Results: The metastatic sites included the brain $(n=16)$, adrenal gland $(n=3)$, spleen $(n=1)$ and jejunum $(n=1)$. Negative conversion of the primary PD-L1-positive NSCLC and positive conversion of the primary PD-L1-negative NSCLC were observed in $3(14 \%)$ and $2(10 \%)$ cases, respectively. Radiotherapy for the metastatic brain lesion before its resection showed a significant relationship with the positive conversion of the primary PD-L1-negative NSCLC ( $p=0.048)$. Conclusion: Radiotherapy-derived effects may contribute to the positive conversion of the primary PD-L1-negative NSCLC.
\end{abstract}

Lung cancer is the leading cause of cancer-related death worldwide (1). Non-small cell lung cancer (NSCLC), which accounts for $85-90 \%$ of lung cancer cases, is the most

Correspondence to: Gouji Toyokawa, Department of Surgery and Science, Graduate School of Medical Sciences, Kyushu University, Fukuoka 812-8582, Japan. Tel: +81 926425466, Fax: +81 926425482,e-mail: gouji104kawa@gmail.com

Key Words: Programmed cell death-ligand 1, immunotherapy, nonsmall cell lung cancer. common form of disease (2). Recently, immunotherapy targeting programmed cell death-1 (PD-1) or programmed cell death-ligand 1 (PD-L1) has gathered a great deal of attention as a novel pharmacological treatment since immunotherapy was reported to be associated with significantly longer progression-free survival (PFS) and overall survival (OS) in comparison to chemotherapy in patients with NSCLC in the CheckMate-017, CheckMate057 and KEYNOTE-024 trials (3-5).

PD-L1 has been revealed to play a pivotal role in the suppression of the anti-tumor immune responses through its binding to the PD-1 receptor, which is expressed on activated $\mathrm{T}$ cells (6). Accordingly, the high expression of PD-L1 on tumor cells (TCs) has been shown to be associated with poor survival in patients with $\operatorname{NSCLC}(7,8)$. Based on the results of clinical trials, the proportion of PD-L1-positive TCs is considered to be a predictive biomarker that can be used to select patients who will benefit from immunotherapy (3-5). Thus, assessing the expression of PD-L1 on the TCs is essential for determining the optimal therapeutic strategies for patients with NSCLC.

On the other hand, in clinical practice, the efficacy of pharmacotherapy, including immunotherapy, often differs between primary lung cancer and metastatic lesions especially brain metastases (9). A recent study showed that heterogeneity in the expression of immune-markers depended on the metastatic sites and histological transformation (10). It is important to investigate the consistency of the PD-L1 expression in primary tumors and their metastatic lesions.

The aim of this study was to investigate the concordance in the expression of PD-L1 between primary lung cancer and metastatic lesions in NSCLC patients. 


\section{Patients and Methods}

Patients. From January 2005 to December 2016, 15 patients were diagnosed with NSCLC and underwent surgical resection of both the primary lung cancer and the corresponding metastatic lesions at the Department of Surgery and Science, Graduate School of Medical Sciences and Department of Neurosurgery, Kyushu University. In the same period, 6 patients were diagnosed with NSCLC based on the pathological examination of biopsy specimens and underwent the surgical resection of the metastatic tumors (alone) with curative intent or for the purpose of palliation. In total, 21 patients with NSCLC were enrolled in the present retrospective study. The variables that were included in this retrospective analysis included age, sex, smoking status (pack year index) and performance status. In the present study, the clinical or pathological $\mathrm{T}$ and $\mathrm{N}$ stage, metastatic site, histopathological subtype and EGFR mutation status of the primary tumor and the corresponding metastatic lesion were investigated. The clinical or pathological stage was determined according to the TNM Classification of Malignant Tumors (7th edition). We analyzed the procedure and therapy for the primary tumor, and local therapy for metastasis. We also investigated the simultaneity of the paired tumors. The present study was approved by our institution's review board.

Immunohistochemical analysis. The surgical or biopsy specimens of the primary tumors and the corresponding metastatic lesions of 21 patients were subjected to an immunohistochemical analysis, as described previously (7). An anti-human PD-L1 rabbit monoclonal antibody (clone SP142, dilution 1:100; Spring Bioscience, Ventana, Tucson, AZ, USA) was used as the primary antibody (7). The PDL1 expression on the membrane of TCs was independently evaluated by a surgeon (S.T.) and a pathologist (K.T.). The percentage of the PD-L1-positive TCs was determined and classified into one of four categories $(0 \%$ : $<1 \% ; 1 \%$ : $1-4 \%$; $5 \%$ : 5 $50 \% ; 50 \%:>50 \%$ ). Lesions in which $\geq 5 \%$ of the TCs were PD-L1positive were considered to be positive (11).

Statistical analysis. Fisher's exact test was used to analyze the association between the PD-L1 positivity of the primary lesions and the corresponding metastases. The relationship between clinical factors and PD-L1 discrepancy between the primary tumors and the corresponding metastases was also investigated using Fisher's exact test. $p$-Values of $<0.05$ were considered to indicate statistical significance. All of the analyses were performed using the JMP ${ }^{\circledR} 13$ software program (SAS Institute Inc., Cary, NC, USA).

\section{Results}

The characteristics of the patients in the present study. Table I shows the characteristics of the patients who were enrolled in the present study. The median age was 63 years (range= $29-79$ years), and $17(81 \%)$ of the patients were male. Eighteen $(86 \%)$ were current and former smokers, and nine (43\%) had $\geq 30$-pack-year smoking history. The performance status of most patients $(86 \%)$ was 0 or 1 . The metastatic sites included the brain, $\mathrm{n}=16(76 \%)$; adrenal gland, $\mathrm{n}=3(14 \%)$; spleen $\mathrm{n}=1(5 \%)$; and jejunum $\mathrm{n}=1(5 \%)$. The diagnoses included adenocarcinoma, $\mathrm{n}=15(72 \%)$; squamous cell
Table I. Characteristics of 21 lung cancer patients with distant metastasis.

\begin{tabular}{|c|c|}
\hline Factors & $\begin{array}{c}\text { Value or no. } \\
\text { of patients }\end{array}$ \\
\hline \multicolumn{2}{|l|}{ Age (years) } \\
\hline Median & 63 \\
\hline Range & $29-79$ \\
\hline \multicolumn{2}{|l|}{ Gender } \\
\hline Male & 17 \\
\hline Female & 4 \\
\hline \multicolumn{2}{|l|}{ Smoking status } \\
\hline Never-smoker & 3 \\
\hline Smoker & 18 \\
\hline \multicolumn{2}{|l|}{ Pack year } \\
\hline$<30$ & 12 \\
\hline$\geq 30$ & 9 \\
\hline \multicolumn{2}{|l|}{ Performance status } \\
\hline 0 & 9 \\
\hline$\geq 1$ & 12 \\
\hline \multicolumn{2}{|l|}{ Metastatic site } \\
\hline Brain & 16 \\
\hline Adrenal gland & 3 \\
\hline Spleen & 1 \\
\hline Jejunum & 1 \\
\hline \multicolumn{2}{|l|}{ Histological type } \\
\hline Adenocarcinoma & 15 \\
\hline Squamous cell carcinoma & 4 \\
\hline Non-small cell lung cancer & 2 \\
\hline \multicolumn{2}{|l|}{$E G F R$ mutation } \\
\hline Wild-type & 16 \\
\hline L858R & 4 \\
\hline 19 deletion & 1 \\
\hline \multicolumn{2}{|l|}{ Procedure for primary tumor } \\
\hline Surgery & 14 \\
\hline Biopsy & 7 \\
\hline \multicolumn{2}{|l|}{ Therapy for primary tumor } \\
\hline Surgery alone & 15 \\
\hline Chemoradiotherapy & 2 \\
\hline Chemotherapy & 3 \\
\hline Radiotherapy & 1 \\
\hline \multicolumn{2}{|c|}{ Radiotherapy for the metastasis before surgery } \\
\hline \multicolumn{2}{|l|}{ Stereotactic radiosurgery } \\
\hline \multicolumn{2}{|l|}{2 (brain) } \\
\hline None & 19 \\
\hline \multicolumn{2}{|l|}{ Simultaneity } \\
\hline Metachronous & 9 \\
\hline Synchronous & 12 \\
\hline
\end{tabular}

$E G F R$, Epidermal growth factor receptor.

carcinoma, $\mathrm{n}=4$ (18\%); and non-small cell lung cancer, $\mathrm{n}=2$ (10\%). The EGFR mutation statuses of the primary tumors and their corresponding metastases were consistent in all cases. None of the patients received molecular-targeted agents immediately before surgical resection. Fourteen patients $(67 \%)$ underwent surgical resection of both the primary and metastatic tumors. In the remaining $7(33 \%)$ 


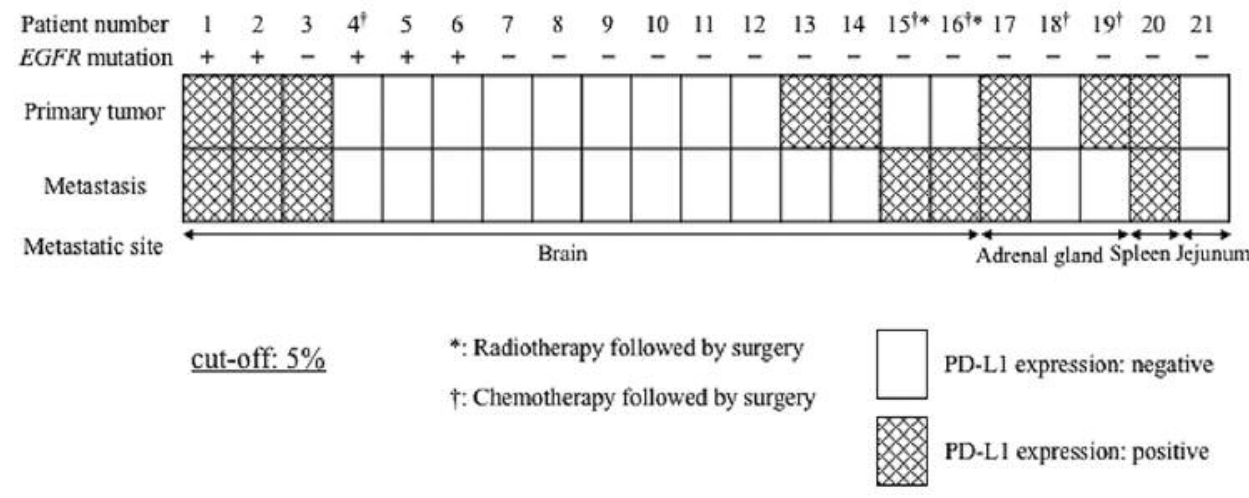

Figure 1. Programmed cell death-ligand 1 expression in 21 primary tumors and their corresponding metastases (cut-off: 5\%).

Table II. Relationship between the clinical factors and PD-L1 discrepancy between 21 primary tumors and their corresponding metastases.

\begin{tabular}{|c|c|c|c|c|c|}
\hline \multirow[t]{2}{*}{ Factors } & & \multirow[t]{2}{*}{$\mathrm{N}$} & \multicolumn{2}{|c|}{ Discrepancy } & \multirow[t]{2}{*}{$p$-Value } \\
\hline & & & $-(n=16)$ & $+(\mathrm{n}=5)$ & \\
\hline \multirow{2}{*}{ Smoking history } & Pack year $<30$ & 12 & $11(92 \%)$ & $1(8 \%)$ & \multirow[t]{2}{*}{0.119} \\
\hline & Pack year $\geq 30$ & 9 & $5(56 \%)$ & $4(44 \%)$ & \\
\hline \multirow[t]{2}{*}{$E G F R$} & Wild-type & 16 & $11(69 \%)$ & $5(31 \%)$ & \multirow[t]{2}{*}{0.278} \\
\hline & Mutant & 5 & $5(100 \%)$ & $0(0 \%)$ & \\
\hline \multirow[t]{2}{*}{ Radiotherapy for the metastasis before surgery } & Stereotactic radiosurgery & 2 & $0(0 \%)$ & $2(100 \%)$ & \multirow[t]{2}{*}{0.048} \\
\hline & None & 19 & $16(84 \%)$ & $3(16 \%)$ & \\
\hline \multirow[t]{2}{*}{ Simultaneity } & Metachronous & 9 & $6(67 \%)$ & $3(33 \%)$ & \multirow[t]{2}{*}{0.611} \\
\hline & Synchronous & 12 & $10(83 \%)$ & $2(17 \%)$ & \\
\hline
\end{tabular}

PD-L1, Programmed cell death ligand-1; EGFR, epidermal growth factor receptor.

patients, the primary lung cancer was biopsied and the metastatic tumors alone were surgically resected with curative intent or for palliation. Immediately before the surgical resection of the metastatic lesions, 5 patients (24\%) received chemotherapy for the primary tumor, and two (10\%) underwent radiotherapy for metastatic lesions (brain). Nine patients $(43 \%)$ had metachronous lesions (the interval between the procedures for the primary and metastatic tumors were $>6$ months).

Discordance in the PD-L1 expression of primary lung cancers and their corresponding metastases. Figure 1 shows the PD-L1 positivity or negativity of the 21 primary tumors and their corresponding metastases with a cut-off value of $5 \%$ (11). When the cut-off value of the proportion of PD-L1positive TCs was set at $5 \%(11), 8$ primary lesions $(38 \%)$ and 7 metastases (33\%) were classified as PD-L1-positive. The metastatic sites, EGFR mutation status and the presence or absence of radiotherapy/chemotherapy immediately before the surgical treatment of the metastatic lesions are also shown. The primary tumors of 8 of the 21 cases (38\%) were positive for PD-L1. Among the 8 patients with PD-L1positive primary lung cancer, the corresponding metastases were PD-L1-negative in 3 cases (38\%). Among the 12 cases $(57 \%)$ in which the primary lung tumor was PD-L1-negative, the corresponding metastatic lesions of two cases $(17 \%)$ were PD-L1-positive. Discrepancy was observed in the PDL1 expression of the primary tumors and their corresponding metastases in 5 of 21 cases $(24 \%)$; the consistency was not statistically significant $(p=0.056)$.

Relationship between the clinical factors and PD-L1 discrepancy between the primary tumors and their corresponding metastases. The association between the clinical factors and PD-L1 discrepancy between the primary tumors and the corresponding metastatic lesions is shown in 
Table II. The administration of radiotherapy for the metastatic brain lesion before its resection showed a significant relationship with discordance in the expression of PD-L1 $(p=0.048)$. On the other hand, heavy smoking (pack year index $\geq 30$ ), EGFR wild-type and the interval between the procedures for the primary and metastatic tumors were not associated with discrepancy in the expression of PD-L1 ( $p=0.119, p=0.278$ and $p=0.611$, respectively).

\section{Discussion}

Patients with NSCLC often develop distant metastases either at the initial diagnosis or during the progression of the disease (2). Approximately $30-50 \%$ of NSCLC patients are expected to develop metastatic central nervous system (CNS) lesions at some point $(12,13)$. However, systemic therapy for CNS disease is associated with a low response rate due to various factors, including the blood-brain barrier, interstitial pressure and efflux pumps (14). In spite of the inadequate penetration of antitumor drugs, platinum-doublet or -triplet regimens are associated with response rates of 23$61.2 \%(15,16)$. Moreover, there is a great deal of evidence to support the efficacy of EGFR- or ALK-TKIs in the treatment of CNS lesions - the response rate is reported to range from 52-82\% (17-23). Regarding immunotherapy targeting PD-1/PD-L1, a previous phase-2 trial showed that the administration of pembrolizumab to treat brain metastases achieved an objective response rate of 33\% (24). According to some case reports, the efficacy of anti-PD1/PD-L1 drugs differs between primary lesion and their metastatic sites (9). It is unclear whether this discrepancy is due to the inadequate delivery of immunotherapeutic agents or the discordant expression of PD-L1 between the primary and metastatic tumors. Given that PD-L1 is a biomarker that can be used to select primary lung cancer patients who will benefit from anti-PD-1/anti-PD-L1 agents (3-5), the investigation of the PD-L1 expression in metastatic lesions as well as primary lesions, and the elucidation of the concordance of the PD-L1 expression between primary and metastatic lesions is important for understanding why the efficacy of immunotherapy differs between primary and metastatic foci.

Although it is rare to find cases in which specimens of both the primary and metastatic tumors are available for an analysis to investigate the expression of PD-L1, some studies have focused on the disagreement in the PD-L1 expression of primary tumors and their metastatic lesions in NSCLC (11, 25). For example, Mansfield et al. reported that discordance was found in the expression of PD-L1 between primary lung cancer tumors and their corresponding metastatic brain lesions in 10 of 73 cases (14\%); the level of PD-L1 expression was decreased in the metastatic tumors of 9 of the 10 cases $(90 \%)$ (11). In the current study, PD-L1 discordance was found in 5 of 21 cases (24\%), with 3 of the 5 cases $(60 \%)$ showing a decreased level of PD-L1 expression at the metastatic site; this was in line with the results of these previous reports $(11,25)$. These data would partly explain why the efficacy of immune checkpoint inhibitors differs between primary tumor and metastases (9).

Our study suggested that radiotherapy for the brain metastasis followed by intracranial surgery was significantly associated with conversion to PD-L1 positivity ( $p=0.048$; Table II), although the sample size was very small. According to the recent pre-clinical studies, the PD-L1 expression on Kras tumor cells was upregulated after radiotherapy $(26,27)$. In addition, while the rate of PD-L1 positivity in NSCLC is reported to range from $24-57 \%$ (7), the rate of PD-L1 positivity in NSCLC patients who received concurrent chemoradiotherapy was $>70 \%$ (28). In our study, both the patients who received local radiotherapy for brain metastases were converted and became PD-L1-positive (Figure 1; patient numbers 15 and 16). The two patients also received systemic chemotherapy, but one patient with brain metastasis who had received chemotherapy followed by intracranial surgery did not exhibit a positive conversion (Figure 1; patient number, 4). These data suggest that radiotherapy might induce PD-L1 positivity, even if the primary tumor does not express the PD-L1 protein.

Dudnik et al. reported the rare case of a patient whose primary and metastatic lesions showed different responses to nivolumab (progressive disease [primary] and stable disease [brain]) (9). According to the report, the patient underwent brain radiotherapy and was then treated with an anti-PD-1 drug. However, the PD-L1 expression was not analyzed in both primary lesions and brain lesions (9). Taking into account that the overexpression of PD-L1 was reported to be a biomarker for the response to PD-1/PD-L1 antibodies (30), our study may partly contribute to evidence of the efficacy of combining radiotherapy with the anti-PD-1 treatment. These findings might be of some help for clinicians to decide upon treatment strategies including the sequence of the therapies.

The present retrospective study is associated with several limitations. First, this study investigated a small cohort of patients with heterogeneous metastatic lesions. Even though it should be emphasized that the paired primary and metastatic samples are rarely available in individual patients, the small number of the cases makes it difficult to draw definite conclusions. Second, we used six biopsy specimens (29\%) to assess the PD-L1 expression in primary lung cancer. While Kitazono et al. showed that the concordance rate of PD-L1 positivity between biopsy samples and resected specimens was $92 \%$ (31). Ilie et al. reported that the concordance rate was 52\% (32). Given this discrepancy, surgically resected specimens would seem preferable for this kind of study. 
With regard to another limitation associated with the technical methods, we analyzed only the PD-L1 expression on TCs. Because the PD-L1 expression on TCs is a reliable biomarker to predict the response to checkpoint blockades, this method may be appropriate to discuss the discrepant efficacy of immune checkpoint inhibitors between primary and metastatic tumors $(33,34)$. However, some previous reports have shown that tumor-infiltrating lymphocytes (TILs) were significantly associated with outcomes in patients treated with checkpoint blockades (35). In addition, the PD-L1 expression on immune cells, but not on TCs, was reported to be related to favorable prognosis in head and neck cancer patients (36). Thus, the investigation of TILs in primary and metastatic tumors is necessary in future studies.

In conclusion, discordance in the expression of PD-L1 between primary lesions and their corresponding metastases was observed in $24 \%$ of the cases in the present study. Radiotherapy-derived effects may partly explain the discrepancy in the expression of PD-L1. Further studies are necessary to validate these findings.

\section{Conflicts of Interest}

Yoichi Nakanishi has received honoraria and research funding from Chugai Pharmaceutical Co. Ltd. Isamu Okamoto has received honoraria from Chugai Pharmaceutical Co. Ltd. All remaining authors declare no conflicts of interest.

\section{Acknowledgements}

The Authors thank Brian T. Quinn for his critical comments on the manuscript.

\section{References}

1 Torre LA, Bray F, Siegel RL, Ferlay J, Lortet-Tieulent J and Jemal A: Global cancer statistics, 2012. CA Cancer J Clin 65: 87-108, 2015.

2 Ettinger DS, Akerley W, Bepler G, Blum MG, Chang A, Cheney RT, Chirieac LR, D'Amico TA, Demmy TL, Ganti AK, Govindan R, Grannis FW Jr., Jahan T, Jahanzeb M, Johnson DH, Kessinger A, Komaki R, Kong FM, Kris MG, Krug LM, Le QT, Lennes IT, Martins R, O’Malley J, Osarogiagbon RU, Otterson GA, Patel JD, Pisters KM, Reckamp K, Riely GJ, Rohren E, Simon GR, Swanson SJ, Wood DE and Yang SC: Non-small cell lung cancer. J Natl Compr Canc Netw 8: 740-801, 2010.

3 Brahmer J, Reckamp KL, Baas P, Crino L, Eberhardt WE, Poddubskaya E, Antonia S, Pluzanski A, Vokes EE, Holgado E, Waterhouse D, Ready N, Gainor J, Aren Frontera O, Havel L, Steins M, Garassino MC, Aerts JG, Domine M, Paz-Ares L, Reck M, Baudelet C, Harbison CT, Lestini B and Spigel DR: Nivolumab versus docetaxel in advanced squamous-cell nonsmall-cell lung cancer. N Engl J Med 373: 123-135, 2015.

4 Borghaei H, Paz-Ares L, Horn L, Spigel DR, Steins M, Ready NE, Chow LQ, Vokes EE, Felip E, Holgado E, Barlesi F, Kohlhaufl M, Arrieta O, Burgio MA, Fayette J, Lena H,
Poddubskaya E, Gerber DE, Gettinger SN, Rudin CM, Rizvi N, Crino L, Blumenschein GR Jr., Antonia SJ, Dorange C, Harbison CT, Graf Finckenstein F and Brahmer JR: Nivolumab versus docetaxel in advanced nonsquamous non-small-cell lung cancer. N Engl J Med 373: 1627-1639, 2015.

5 Reck M, Rodriguez-Abreu D, Robinson AG, Hui R, Csoszi T, Fulop A, Gottfried M, Peled N, Tafreshi A, Cuffe S, O'Brien M, Rao S, Hotta K, Leiby MA, Lubiniecki GM, Shentu Y, Rangwala $\mathrm{R}$ and Brahmer JR: Pembrolizumab versus chemotherapy for PD-L1-positive non-small-cell lung cancer. $\mathrm{N}$ Engl J Med 375: 1823-1833, 2016.

6 Pardoll DM: The blockade of immune checkpoints in cancer immunotherapy. Nat Rev Cancer 12: 252-264, 2012.

7 Takada K, Okamoto T, Shoji F, Shimokawa M, Akamine T, Takamori S, Katsura M, Suzuki Y, Fujishita T, Toyokawa G, Morodomi Y, Okano S, Oda Y and Maehara Y: Clinical significance of PD-L1 protein expression in aurgically resected primary lung adenocarcinoma. J Thorac Oncol 11: 1879-1890, 2016.

8 Sun JM, Zhou W, Choi YL, Choi SJ, Kim SE, Wang Z, DolledFilhart M, Emancipator K, Wu D, Weiner R, Frisman D, Kim HK, Choi YS, Shim YM and Kim J: Prognostic significance of PD-L1 in patients with non-small cell lung cancer: a large cohort study of surgically resected cases. J Thorac Oncol 11: 1003-1011, 2016.

9 Dudnik E, Yust-Katz S, Nechushtan H, Goldstein DA, Zer A, Flex D, Siegal $\mathrm{T}$ and Peled $\mathrm{N}$ : Intracranial response to nivolumab in NSCLC patients with untreated or progressing CNS metastases. Lung cancer (Amsterdam, Netherlands) 98: 114-117, 2016.

10 Suda K, Murakami I, Yu H, Kim J, Ellison K, Rivard CJ, Mitsudomi T and Hirsch FR: Heterogeneity in Immune Marker Expression after acquisition of resistance to EGFR kinase inhibitors: analysis of a case with small cell lung cancer transformation. J Thorac Oncol 12: 1015-1020, 2017.

11 Mansfield AS, Aubry MC, Moser JC, Harrington SM, Dronca RS, Park SS and Dong H: Temporal and spatial discordance of programmed cell death-ligand 1 expression and lymphocyte tumor infiltration between paired primary lesions and brain metastases in lung cancer. Ann Oncol 27: 1953-1958, 2016.

12 Nayak L, Lee EQ and Wen PY: Epidemiology of brain metastases. Current oncology reports 14: 48-54, 2012.

13 Chao JH, Phillips R and Nickson JJ: Roentgen-ray therapy of cerebral metastases. Cancer 7: 682-689, 1954.

14 Pitz MW, Desai A, Grossman SA and Blakeley JO: Tissue concentration of systemically administered antineoplastic agents in human brain tumors. J Neurooncol 104: 629-638, 2011.

15 Zimmermann S, Dziadziuszko R and Peters S: Indications and limitations of chemotherapy and targeted agents in non-small cell lung cancer brain metastases. Cancer Treat Rev 40: 716-722, 2014.

16 Besse B, Le Moulec S, Mazieres J, Senellart H, Barlesi F, Chouaid C, Dansin E, Berard H, Falchero L, Gervais R, Robinet G, Ruppert AM, Schott R, Lena H, Clement-Duchene C, Quantin X, Souquet PJ, Tredaniel J, Moro-Sibilot D, Perol M, Madroszyk AC and Soria JC: Bevacizumab in patients with nonsquamous non-small cell lung cancer and asymptomatic, Untreated Brain Metastases (BRAIN): A Nonrandomized, Phase II Study. Clin Cancer Res 21: 1896-1903, 2015.

17 Hata A and Katakami N: Afatinib for Erlotinib Refractory Brain Metastases in a patient with EGFR-mutant non-small-cell lung cancer: can high-affinity TKI substitute for high-dose TKI? J Thorac Oncol 10: e65-66, 2015. 
18 Bai $\mathrm{H}$ and Han B: The effectiveness of erlotinib against brain metastases in non-small cell lung cancer patients. Am J Clin Oncol 36: 110-115, 2013.

19 Gainor JF, Chi AS, Logan J, Hu R, Oh KS, Brastianos PK, Shih HA and Shaw AT: Alectinib dose escalation reinduces central nervous system responses in patients with anaplastic lymphoma kinase-positive non-small cell lung cancer relapsing on standard dose alectinib. J Thorac Oncol 11: 256-260, 2016.

20 Gainor JF, Sherman CA, Willoughby K, Logan J, Kennedy E, Brastianos PK, Chi AS and Shaw AT: Alectinib salvages CNS relapses in ALK-positive lung cancer patients previously treated with crizotinib and ceritinib. J Thorac Oncol 10: 232-236, 2015.

21 Toyokawa G, Seto T, Takenoyama M and Ichinose Y: Insights into brain metastasis in patients with ALK+ lung cancer: is the brain truly a sanctuary? Cancer Metastasis Rev 34: 797-805, 2015.

22 Gadgeel SM, Gandhi L, Riely GJ, Chiappori AA, West HL, Azada MC, Morcos PN, Lee RM, Garcia L, Yu L, Boisserie F, Di Laurenzio L, Golding S, Sato J, Yokoyama S, Tanaka T and Ou SH: Safety and activity of alectinib against systemic disease and brain metastases in patients with crizotinib-resistant ALKrearranged non-small-cell lung cancer (AF-002JG): results from the dose-finding portion of a phase 1/2 study. Lancet Oncol 15: 1119-1128, 2014.

23 Porta R, Sanchez-Torres JM, Paz-Ares L, Massuti B, Reguart N, Mayo C, Lianes P, Queralt C, Guillem V, Salinas P, Catot S, Isla D, Pradas A, Gurpide A, de Castro J, Polo E, Puig T, Taron M, Colomer R and Rosell R: Brain metastases from lung cancer responding to erlotinib: the importance of EGFR mutation. Eur Respir J 37: 624-631, 2011.

24 Goldberg SB, Gettinger SN, Mahajan A, Chiang AC, Herbst RS, Sznol M, Tsiouris AJ, Cohen J, Vortmeyer A, Jilaveanu L, Yu J, Hegde U, Speaker S, Madura M, Ralabate A, Rivera A, Rowen E, Gerrish H, Yao X, Chiang V and Kluger HM: Pembrolizumab for patients with melanoma or non-small-cell lung cancer and untreated brain metastases: early analysis of a non-randomised, open-label, phase 2 trial. Lancet Oncol 17: 976-983, 2016.

25 Kim MY, Koh J, Kim S, Go H, Jeon YK and Chung DH: Clinicopathological analysis of PD-L1 and PD-L2 expression in pulmonary squamous cell carcinoma: Comparison with tumorinfiltrating $\mathrm{T}$ cells and the status of oncogenic drivers. Lung cancer (Amsterdam, Netherlands) 88: 24-33, 2015.

26 Herter-Sprie GS, Koyama S, Korideck H, Hai J, Deng J, Li YY, Buczkowski KA, Grant AK, Ullas S, Rhee K, Cavanaugh JD, Neupane NP, Christensen CL, Herter JM, Makrigiorgos GM, Hodi FS, Freeman GJ, Dranoff G, Hammerman PS, Kimmelman AC and Wong KK: Synergy of radiotherapy and PD-1 blockade in Kras-mutant lung cancer. JCI insight 1: e87415, 2016.

27 Gong X, Li X, Jiang T, Xie H, Zhu Z, Zhou F and Zhou C: Combined radiotherapy and anti-PD-L1 antibody synergistically enhances antitumor effect in non-small cell lung cancer. J Thorac Oncol 12: 1085-1097, 2017
28 Tokito T, Azuma K, Kawahara A, Ishii H, Yamada K, Matsuo N, Kinoshita T, Mizukami N, Ono H, Kage M and Hoshino T: Predictive relevance of PD-L1 expression combined with CD8 ${ }^{+}$ TIL density in stage III non-small cell lung cancer patients receiving concurrent chemoradiotherapy. Eur J Cancer 55: 7-14, 2016.

29 Dagogo-Jack I, Lanfranchi M, Gainor JF, Giobbie-Hurder A, Lawrence DP, Shaw AT and Sullivan RJ: A Retrospective analysis of the efficacy of pembrolizumab in melanoma patients with brain metastasis. J Immunother 40: 108-113, 2017.

30 Meng X, Huang Z, Teng F, Xing L and Yu J: Predictive biomarkers in PD-1/PD-L1 checkpoint blockade immunotherapy. Cancer Treat Rev 41: 868-876, 2015.

31 Kitazono S, Fujiwara Y, Tsuta K, Utsumi H, Kanda S, Horinouchi H, Nokihara H, Yamamoto N, Sasada S, Watanabe $\mathrm{S}$, Asamura H, Tamura T and Ohe Y: Reliability of small biopsy samples compared with resected specimens for the determination of programmed death-ligand 1 expression in non--small-cell lung cancer. Clinical Lung Cancer 16: 385-390, 2015.

32 Ilie M, Long-Mira E, Bence C, Butori C, Lassalle S, Bouhlel L, Fazzalari L, Zahaf K, Lalvee S, Washetine K, Mouroux J, Venissac N, Poudenx M, Otto J, Sabourin JC, Marquette CH, Hofman V and Hofman P: Comparative study of the PD-L1 status between surgically resected specimens and matched biopsies of NSCLC patients reveal major discordances: a potential issue for anti-PD-L1 therapeutic strategies. Ann Oncol 27: 147-153, 2016.

33 Reck M, Rodriguez-Abreu D, Robinson AG, Hui R, Csoszi T, Fulop A, Gottfried M, Peled N, Tafreshi A, Cuffe S, O'Brien M, Rao S, Hotta K, Leiby MA, Lubiniecki GM, Shentu Y, Rangwala $\mathrm{R}$ and Brahmer JR: Pembrolizumab versus chemotherapy for PDL1-positive non-small-cell lung cancer. N Engl J Med 375: 1823$1833,2016$.

34 Meng X, Huang Z, Teng F, Xing L and Yu J: Predictive biomarkers in PD-1/PD-L1 checkpoint blockade immunotherapy. Cancer Treat Rev 41: 868-876, 2015.

35 Shien K, Papadimitrakopoulou VA and Wistuba II: Predictive biomarkers of response to PD-1/PD-L1 immune checkpoint inhibitors in non-small cell lung cancer. Lung cancer (Amsterdam, Netherlands) 99: 79-87, 2016.

36 Kim HR, Ha SJ, Hong MH, Heo SJ, Koh YW, Choi EC, Kim EK, Pyo KH, Jung I, Seo D, Choi J, Cho BC and Yoon SO: PDL1 expression on immune cells, but not on tumor cells, is a favorable prognostic factor for head and neck cancer patients. Sci Rep 6: 36956, 2016. 